\title{
$\mathrm{C}|\mathrm{N}| \mathrm{A}$
}

The $2^{\text {nd }}$ Conference on Innovation and Industrial Applications (CINIA 2016)

\section{Analisa Uji Sifat Penguapan Pada Gasoline}

\author{
Indah Dhamayanthie ${ }^{1}$, Shelly Octaviana ${ }^{2} \&$ Yully Mulyani $^{3}$ \\ ${ }^{1}$ Teknik Kimia, Akademi Minyak dan Gas Balongan \\ ${ }^{2}$ Teknik Kimia, Akademi Minyak dan Gas Balongan \\ ${ }^{3}$ Teknik Kimia, Akademi Minyak dan Gas Balongan \\ Email : idhamayanthie@gmail.com
}

\begin{abstract}
Abstrak
Tujuan penelitian untuk mengetahui metode yang digunakan untuk mengukur sifat penguapan pada gasoline dan untuk mengetahui dan memahami spesifikasi yang diperbolehkan untuk gasoline menguap. Pengujian yang dilakukan terdapat 4 sampel gasoline yaitu premium, pertalite, pertamax dan pertamax plus. Sampel kemudian diuji sifat penguapannya dengan mengacu ke ASTM D 323 untuk RVP (Reid Vapour Pressure) dan ASTM D 86 untuk distilasi. Dari pengujian Semakin besar nilai RVP pada gasoline makin rendah juga temperature yang didapat dari pengujian distilasi $10 \%$ volume penguapan yang mempengaruhi semakin mudahnya motor dinyalakan pada kondisi dingin. Semakin tinggi RVP dari gasoline makin rendah pula temperature yang didapatkan pada pengujian distilasi $90 \%$ volume penguapan ini akan mempengaruhi kemudahan pada pendistribusian bahan bakar ke setiap silinder mesin. Pada pengujian semakin tinggi angka oktan dari suatu bahan bakar bensin (gasoline), maka akan semakin bagus pula sifat penguapannya baik dari hasil uji distilasi maupun uji RVP nya. Dari hasil pengujian yang dilakukan baik pengujian distilasi atau RVP ke empat sampel beda angka oktan tersebut tidak kurang dari batas maksimum dan minimum spesifikasi uji sifat penguapan yang dikeluarkan dirjen migas tahun 2013.
\end{abstract}

Kata kunci: Distilasi, Gasoline, Penguapan, Premium dan Pertalite

\section{PENDAHULUAN}

Minyak bumi adalah suatu campuran yang sangat kompleks yang terutama terdiri dari senyawa-senyawa hidrokarbon yaitu senyawa-senyawa organik dimana setiap molekulnya hanya mempunyai unsur karbon dan hidrogen saja. Baik senyawa hidrokarbon maupun bukan senyawa hidrokarbon keduanya akan berpengaruh dalam menentukan cara-cara pengolahan yang dilakukan dalam kilang. Maka dengan berkembangnya teknologi dewasa ini, kebutuhan akan bahan bakar minyak bumi semakin banyak karena lebih ekonomis, tersedia dalam jumlah banyak, mudah dibawa dan bersih. Misalnya untuk bahan bakar motor gasoline seperti premium, sangatlah besar kebutuhannya, padahal unit kilang sangatlah terbatas keberadaannya sehingga diperlukan suatu proses lanjutan yang disebut proses konversi, blending dan proses lain yang dapat menunjang kebutuhan ini[1].

Hasil dari primary proses maupun secondary proses, pada prinsipnya masih perlu dilakukan perbaikan-perbaikan dan pengujian pada sifat-sifat atau karakteristik tertentu yang mungkin belum dapat memenuhi persyaratan pasaran. Untuk menentukan komposisi serta kualitas produk minyak bumi maka perlu dilakukan uji-uji seperti uji destilasi yang akan digunakan untuk memisahkan fraksi-fraksi minyak bumi. Pada umumnya uji minyak bumi dapat dilakukan dengan cepat, mudah dibuat duplikat oleh teknisi laboraturium biasa dan hasil ujinya dapat diinterpretasikan sebagai fungsi kinerja produk selama penggunaan. Disamping itu uji rutin juga dikerjakan dalam laboratorium. Karena sangat banyaknya uji, maka hanya beberapa macam uji yang sering dijumpai, maka dalam karya ilmiah ini uji yang akan dibahas mengenai uji RVP terhadap motor gasoline seperti bensin yang berdasarkan sifat penguapannya. Karena banyaknya sifat-sifat yang diperlukan bagi bensin motor, sifat penguapan mempunyai pengaruh penting dalam operasi mesin. Sifat ini diatur sedemikian rupa sehingga untuk setiap keadaan dapat diperoleh campuran bahan bakar dan udara yang ideal, untuk menjamin terjadinya pembakaran yang sempurna di ruang bakar. Sebaiknya jangan terlalu mudah menguap, sehingga menimbulkan vapour lock dan pembentukan butir-butir es di dalam karbulator, sedangkan bila sukar menguap akan menyebabkan penyebarannya di dalam silinder tidak seimbang, mesin sulit untuk dihidupkan. Hal ini akan menimbulkan karbon deposit serta menyebabkan pengenceran minyak lumas.

\section{TINJAUAN PUSTAKA}

\subsection{Gasoline}


Bensin atau gasoline adalah cairan campuran yang sebagian besar berupa senyawa hidrokarbon (parafin, naftalen, senyawa tidak jenuh dan terkadang senyawa aromatik) yang berasal dari minyak bumi, digunakan sebagai bahan bakar untuk kendaraan bermotor. Istilah gasoline banyak digunakan dalam industri minyak, bahkan dalam perusahaan. Kadangkala istilah mogas (motor gasoline) digunakan untuk membedakannya dengan avgas, gasoline yang digunakan oleh pesawat terbang ringan Secara sederhana, bensin tersusun dari hidrokarbon rantai lurus, mulai dari $\mathrm{C}_{5}$ (Pentane) sampai dengan $\mathrm{C}_{9}$ (Nonana). Dengan kata lain, bensin terbuat dari molekul yang hanya terdiri dari hidrogen dan karbon yang terikat antara satu dengan yang lainnya sehingga membentuk rantai.

Cairan ini mengandung hidrokarbon atom-atom karbon dalam minyak mentah ini berhubungan satu dengan yang lainnya dengan cara membentuk rantai yang panjangnya yang berbeda-beda. Molekul hidrokarbon dengan panjang yang berbeda akan memiliki sifat yang berbeda pula. $\mathrm{CH}_{4}$ (metana) merupakan molekul paling ringan. Bertambahnya atom $\mathrm{C}$ dalam rantai tersebut akan membuatnya semakin berat. Empat molekul pertama hidrokarbon adalah metana, etana, propana, dan $\underline{\text { butana. }}$

Dalam temperatur dan tekanan kamar, keempatnya berwujud gas, dengan titik didih masing-masing $-107^{\circ} \mathrm{C},-67^{\circ} \mathrm{C},-$ $43^{\circ} \mathrm{C}$ dan $-18^{\circ} \mathrm{C}$. Berikutnya, dari $\mathrm{C}_{5}$ sampai dengan $\mathrm{C}_{18}$ berwujud cair, dan mulai dari $\mathrm{C}_{19}$ ke atas berwujud padat. Dengan bertambah panjangnya rantai hidrokarbon akan menaikkan titik didihnya, sehingga pemisahan hidrokarbon ini dilakukan dengan cara distilasi. Prinsip inilah yang diterapkan di pengilangan minyak untuk memisahkan berbagai fraksi hidrokarbon dari minyak mentah.

\subsection{Klasifikasi Gasoline}

Premium (ON 88) adalah bahan bakar jenis distilat berwarna kuning akibat adanya zat pewarna tambahan. Premium pada umumnya digunakan untuk bahan bakar kendaraan bermotor bermesin bensin, seperti mobil, sepeda motor, dan lain lain. Bahan bakar ini juga sering disebut motor gasoline atau petrol dengan angka oktan adalah 88, dan mempunyai titik didih $30^{\circ} \mathrm{C}-200^{\circ} \mathrm{C}$. Bensin premium mempunyai sifat anti ketukan yang baik dan dapat dipakai pada mesin kompresi tinggi pada saat semua kondisi.

Pertalite (ON 90) adalah merupakan Bahan bakar minyak (BBM) jenis baru yang diproduksi Pertamina, Jika dibandingkan dengan premium Pertalite memiliki kualitas bahan bakar lebih baik dibandingkan dengan premium. Pertalite direkomendasikan untuk kendaraan yang memiliki kompresi 9,1-10,1 dan mobil tahun 2000 ke atas.

Pertamax (RON 92), Pertamax ditujukan untuk kendaraan yang mensyaratkan penggunaan bahan bakar beroktan tinggi tanpa timbal. Karena pertamax sudah membatasi kandungan senyawa aromatik yaitu sebesar maksimum 50\% volume dan kandungan benzene sebesar 5\% vol [2].

Pertamax Plus (ON 95) adalah bensin dengan grade mutu yang lebih baik karena sudah membatasi kandungan senyawa aromatik yaitu maksimum sebesar $40 \%$ vol. dan kandungan benzena sebesar $5 \%$ vol. Pertamax plus ditujukan untuk kendaraan berteknologi mutakhir yang mensyaratkan penggunaan bahan bakar beroktan tinggi dan ramah lingkungan. Pertamax plus sangat direkomendasikan untuk kendaraan yang memiliki kompresi ratio lebih besar dari 10,5 dan menggunakan teknologi electronic fuel injection (EFI)[3].

\subsection{Spesifikasi Gasoline Berdasarkan Sifat Penguapan}

Diharapkan bahan bakar akan teruapkan dengan sempurna dan terdistribusi merata didalam ruang bakar yang akan menimbulkan pembakaran sempurna yang mengakibatkan mudahnya starting saat kondisi lingkungan dingin atau pun pada suhu normal, pemanasan pendahuluan dan akselerasi.

Bahan bakar sukar menguap mengakibatkan mesin sulit untuk dihidupkan yang akan mengakibatkan timbulnya deposit karbon. Sedangkan bahan bakar yang mempunyai sifat mudah menguap akan menimbulkan vapor lock yang akan mengakibatkan pembentukan butir es dalam karburator.

\section{METODE PENELITIAN}

Metode uji yang digunakan pada penelitian ini adalah American Society for Testing and Material (ASTMD 86 untuk Distilasi dan ASTMD 323 untuk RVP), sedangkan sampel yang diuji adalah sampel gasoline premium (RON 88), sampel gasoline pertalite (RON 90), sampel gasoline pertamax (RON 92), sampel gasoline pertamax plus (RON 95) yang berjumlah 4 Buah. Dalam penelitian ini, penulis hanya membahas mengenai pengujian RVP dan Distilasi yang termasuk dalam sifat penguapan.

Metoda uji ini mencakup distilasi atmosferik dengan memakai distilasi batch manual ataupun batch automatic dengan \% volume penguapan yang digunakan yaitu, IBP (Initial Boiling Point), 10\% volume penguapan, 50\% volume penguapan, 90\% volume penguapan dan end point untuk menentukan secara kuantitatif karakteristik batasan titik didih produk minyak bumi.

Pengujian Menggunakan Reid Vapour Pressure (RVP) dengan Metode ASTM D 323. Reid Vapour Pressure (RVP) adalah tekanan uap (vapor pressure) liquid pada $100^{\circ} \mathrm{F}$ dalam ukuran absolut (absolute vapor pressure). Makin besar RVP suatu sample menunjukan bahwa sampel tersebut semakin mudah menguap.

Pada dasarnya prinsip kerja dari pengujian RVP yaitu dituangnya sejumlah sampel kedalam tabung baja alat reid dengan alat pemindah sampel khusus, kemudian di rendam dalam bak pada suhu tetap $100^{\circ} \mathrm{F}$, setiap lima menit dilakukan pembacaan tekanan pada alat ukur dan pengocokan, sampai tekanan maksimum yang dihasilkan konstan.

Pengujian ini bertujuan untuk menentukan RVP dari gasoline dan produk petroleum yang mudah menguap serta tidak kental (non viscous). 
Metode uji yang digunakan pada penelitian ini adalah American Society for Testing and Material (ASTM D 86 untuk Distilasi dan ASTM D 323 untuk RVP), sedangkan sampel yang diuji adalah sampel gasoline premium (RON 88), sampel gasoline pertalite (RON 90), sampel gasoline pertamax (RON 92), sampel gasoline pertamax plus (RON 95) yang berjumlah 4 Buah. Dalam penelitian ini, penulis hanya membahas mengenai pengujian RVP dan distilasi yang termasuk dalam sifat penguapan.

\section{HASIL DAN PEMBAHASAN}

Pengujian distilasi dan RVP dari bensin yang dilakukan dalam percobaan ini untuk melihat sifat volatilitas dari beberapa jenis bensin berdasarkan perbedaan dari angka oktananya

\subsection{Hasil Pengujian Distilasi}

Data hasil pengujian distilasi dari beberapa bensin yang dilakukan di laboratorium di ambil pada persentasi recovery mulai dari 5\% volume penguapan sampai dengan $95 \%$ volume penguapan. Hasil pengujian distilasi dari masing-masing jenis bensin premium, pertalite, pertamax dan pertamax plus berturut-turut di sajikan pada Tabel 1 Hasil Pengujian Distilasi pada Premium, Tabel 2 Hasil Pengujian Distilasi dan Reid Vapour Pressure Pertalite, Tabel 3 Hasil Pengujian Distilasi Pada Pertamax dan Tabel 4 Hasil Pengujian Distilasi Pada Pertamax Plus

Tabel 1. Hasil Pengujian Distilasi dan Reid Vapour Pressure pada Premium

\begin{tabular}{|c|c|c|c|c|}
\hline \multirow{2}{*}{$\begin{array}{c}\text { Karakteristik } \\
\text { Premium }\end{array}$} & \multirow{2}{*}{ Satuan } & $\begin{array}{c}\text { Hasil } \\
\text { Pengujian }\end{array}$ & \multicolumn{2}{|c|}{ Batasan } \\
\cline { 4 - 6 } & & & Min & Max \\
\hline $\begin{array}{c}\text { IBP (Initial Boiling } \\
\text { Point) }\end{array}$ & ${ }^{\circ} \mathrm{C}$ & 35 & & \\
\hline 10 VOL PENGUAPAN & ${ }^{\circ} \mathrm{C}$ & 58 & - & 74 \\
\hline 50 VOL PENGUAPAN & ${ }^{\circ} \mathrm{C}$ & 96 & 75 & 125 \\
\hline 90 VOL PENGUAPAN & ${ }^{\circ} \mathrm{C}$ & 176 & - & 180 \\
\hline EP (End Point) & ${ }^{\circ} \mathrm{C}$ & 192 & - & 215 \\
\hline Tekanan Uap Reid & ${ }^{\mathrm{Kpa}}$ & 53,8 & 45 & 69 \\
\hline
\end{tabular}

Tabel 2. Hasil Pengujian Distilasi dan Reid Vapour Pressure Pertalite

\begin{tabular}{|c|c|c|c|c|}
\hline \multirow{2}{*}{$\begin{array}{c}\text { Karakteristik } \\
\text { Pertalite }\end{array}$} & \multirow{2}{*}{ Satuan } & $\begin{array}{c}\text { Hasil } \\
\text { Pengujian }\end{array}$ & \multicolumn{2}{|c|}{ Batasan } \\
\cline { 4 - 5 } & & & Min & Max \\
\hline $\begin{array}{c}\text { IBP (Initial Boiling } \\
\text { Point) }\end{array}$ & ${ }^{\circ} \mathrm{C}$ & 45 & & \\
\hline 10 VOL PENGUAPAN & ${ }^{\circ} \mathrm{C}$ & 57 & - & 74 \\
\hline 50 VOL PENGUAPAN & ${ }^{\circ} \mathrm{C}$ & 96 & 88 & 125 \\
\hline 90 VOL PENGUAPAN & ${ }^{\circ} \mathrm{C}$ & 176 & - & 180 \\
\hline EP (End Point) & ${ }^{\circ} \mathrm{C}$ & 197 & - & 215 \\
\hline Tekanan Uap Reid & $\mathrm{Kpa}$ & 58,0 & 45 & 69 \\
\hline
\end{tabular}

Tabel 3. Hasil Pengujian Distilasi dan Reid Vapour Pressure Pertamax 


\begin{tabular}{|c|c|c|c|c|}
\hline Karakteristik & \multirow{2}{*}{$\begin{array}{c}\text { Satuan } \\
\text { Pertamax }\end{array}$} & $\begin{array}{c}\text { Hasil } \\
\text { Pengujian }\end{array}$ & \multicolumn{2}{|c|}{ Batasan } \\
\cline { 4 - 6 } & & & Min & Max \\
\hline $\begin{array}{c}\text { IBP (Initial Boiling } \\
\text { Point) }\end{array}$ & ${ }^{\circ} \mathrm{C}$ & 37 & & \\
\hline 10 VOL PENGUAPAN & ${ }^{\circ} \mathrm{C}$ & 55 & - & 70 \\
\hline 50 VOL PENGUAPAN & ${ }^{\circ} \mathrm{C}$ & 85 & - & 110 \\
\hline 90 VOL PENGUAPAN & ${ }^{\circ} \mathrm{C}$ & 174 & - & 180 \\
\hline EP (End Point) & ${ }^{\circ} \mathrm{C}$ & 185 & - & 215 \\
\hline Tekanan Uap Reid & $\mathrm{Kpa}$ & 59,3 & 40 & 60 \\
\hline
\end{tabular}

Tabel 4. Hasil Pengujian Distilasi Distilasi dan Reid Vapour Pressure Pada Pertamax Plus

\begin{tabular}{|c|c|c|c|c|}
\hline \multirow{2}{*}{$\begin{array}{c}\text { Karakteristik } \\
\text { Pertamax Plus }\end{array}$} & \multirow{2}{*}{ Satuan } & $\begin{array}{c}\text { Hasil } \\
\text { Pengujian }\end{array}$ & \multicolumn{2}{|c|}{ Batasan } \\
\cline { 4 - 5 } & & & Min & Max \\
\hline $\begin{array}{c}\text { IBP (Initial Boiling } \\
\text { Point) }\end{array}$ & ${ }^{\circ} \mathrm{C}$ & 40 & & \\
\hline 10 VOL PENGUAPAN & ${ }^{\circ} \mathrm{C}$ & 53 & - & 70 \\
\hline 50 VOL PENGUAPAN & ${ }^{\circ} \mathrm{C}$ & 82 & - & 110 \\
\hline 90 VOL PENGUAPAN & ${ }^{\circ} \mathrm{C}$ & 169 & - & 180 \\
\hline EP (End Point) & ${ }^{\circ} \mathrm{C}$ & 185,5 & - & 215 \\
\hline Tekanan Uap Reid & $\mathrm{Kpa}$ & 59,98 & 45 & 60 \\
\hline
\end{tabular}

Dari data hasil pengujian distilasi diatas yang didapatkan semua sampel gasoline baik premium, pertalite, pertamax dan pertamax plus dinyatakan telah memenuhi standar spesifikasi

\subsection{Hasil Pengujian Reid Vapour Pressure (RVP)}

Pengujian RVP bertujuan untuk menentukan keamanan dalam pengangkutan bahan bakar minyak, mengetahui sumbatan uap (vapor lock) dalam sistem pengumpanan bensin, menentukan kemudahan mesin dihidupkan dalam keadaan dingin (starting characteristics), menentukan tipe tangki penyimpanan minyak yang digunakan dan mengetahui kemampuan bensin mensuplai uap yang cukup pada saat starter.

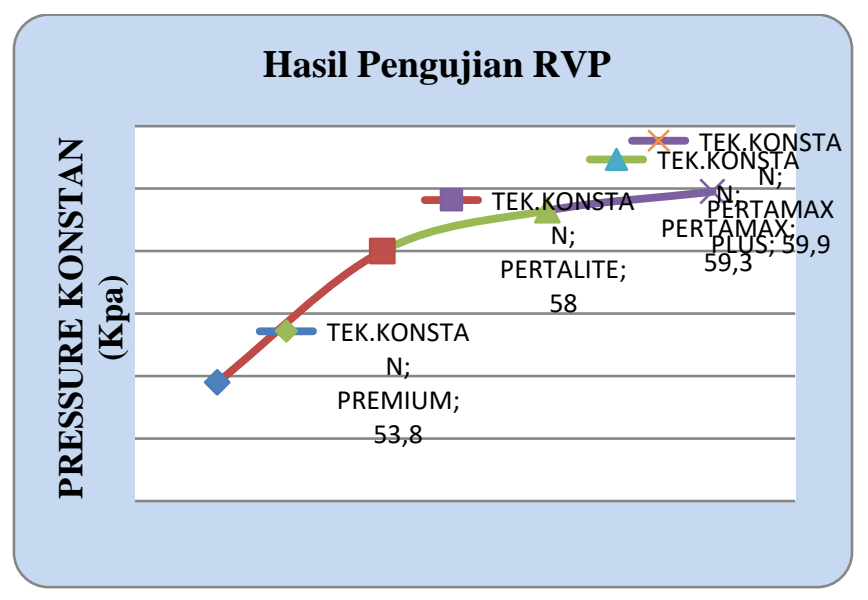

Grafik 1 Reid Vapor Pressure Berdasarkan Angka Oktan

Dari grafik hasil pengujian RVP pada sampel gasoline dengan beda angka oktan seperti premium, pertalite, pertamax dan pertamax plus dapat dilihat garis line grafik yang menunjukkan makin tinggi nilai oktan dari sebuah bahan bakar gasoline makin besar nilai RVP-nya. RVP yang tinggi dapat mengakibatkan pencapaian IBP (Initial Boiling Point) yang cepat yang dapat di artikan cepatnya penyalaan mesin (starting) pada saat kondisi dingin.

Untuk dalam segi keamanan penyimpanan gasoline harus memenuhi standar maksimum tekanan uap gasoline yaitu sebesar $60 \mathrm{kpa}$, dalam hasil sampel pengujian semua sampel pengujian baik premium, pertalite, pertamax dan pertamax plus telah lolos standar minimal nilai tekanan uap $45 \mathrm{kpa}$ dan nilai maksimal dari tekanan uap reid gasoline adalah $60 \mathrm{kpa}$. 


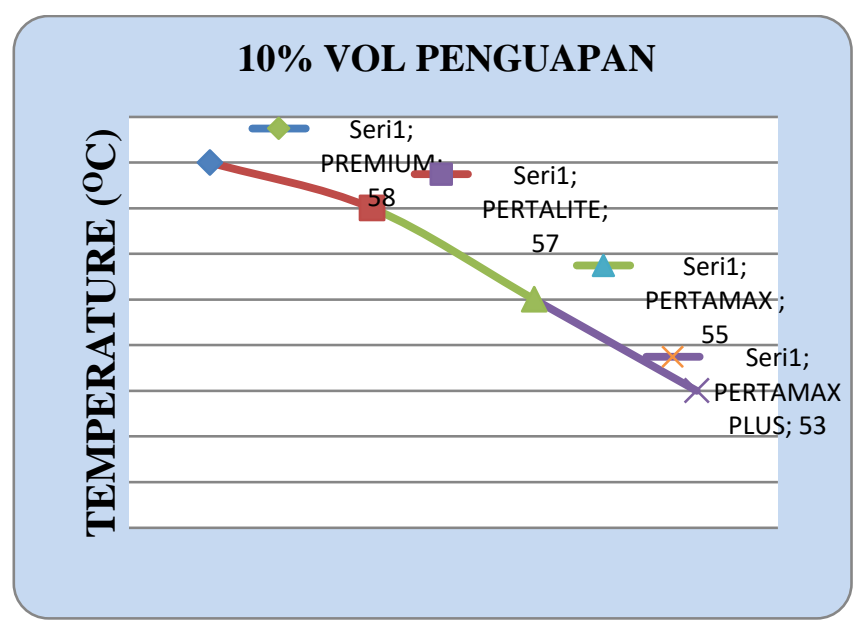

Grafik 2 Distilasi Pada 10\% Volume Penguapan Pada Distilasi

Pada hasil pengujian distilasi pada $10 \%$ volume penguapan, garis grafik menunjukkan makin tinggi nilai oktan sampel bahan bakar, maka makin rendah pula temperaturenya. Pada pengujian 10\% volume penguapan memegang peranan dalam kemudahan menghidupkan mesin pada kondisi dingin. Makin rendah temperature $10 \%$ volume penguapan pada uji distilasi, makin mudah motor dinyalakan pada kondisi dingin.

Dilihat dari grafik hasil pengujian distilasi pada gasoline jenis premium ON 88, pertalite ON 90, pertamax ON 92 dan pertamax plus ON 95, semakin tinggi angka oktan dari suatu bahan bakar maka makin rendah temperature pada saat pengujian $10 \%$ volume penguapan distilasi, maka dapat di tarik kesimpulan bahwa makin tinggi angka oktan dari suatu bahan bakar maka makin mudah motor dinyalakan pada kondisi dingin.

Sifat volatilitas bensin dipengaruhi oleh nilai RVP bensin dan karakteristik distilasi pada 10\% volume penguapan (T10). Kedua karakteristik ini berbanding terbalik. Semakin besar nilai RVP bensin, maka semakin rendah temperatur distilasi pada $10 \%$ volume penguapan (T10) maka semakin mudah bensin menguap. Sifat volatilitas bensin berkaitan dengan pembentukan campuran udara dan bahan bakar yang berpengaruh pada kemulusan operasi mesin kendaraan (driveability), kemudahan penyalaan pada saat dingin (cold starting), mudah mencapai panas (warm up) dan terjadinya sumbatan uap (vapour lock)[4]

Pada pengujian distilasi $10 \%$ vol penguapan mempengaruhi saat bahan bakar masuk ke dalam mesin atau ruang pembakaran dan mempengaruhi loncatan bunga api pada busi, pada teorinya semakin kecil temperature pada $10 \%$ vol penguapan semakin cepat mesin dinyalakan (starter), pada sampel gasoline premium yang di pilih, hasil pengujian yang didapat lebih kecil dari batas maksimum spesifikasi bensin. Dapat di artikan bahwa sampel yang di ambil untuk pengujian starter tergolong mudah dinyalakan pada kondisi dingin.

Jika diurutkan dari sampel yang ada untuk pengujian distilasi $10 \%$ vol penguapan urutan sampel yang paling mudah dinyalakan pada kondisi dingin adalah pertamax plus, pertamax, pertalite dan premium dilihat dari besar RVP dan temperature yang didapat saat pengujian distilasi.

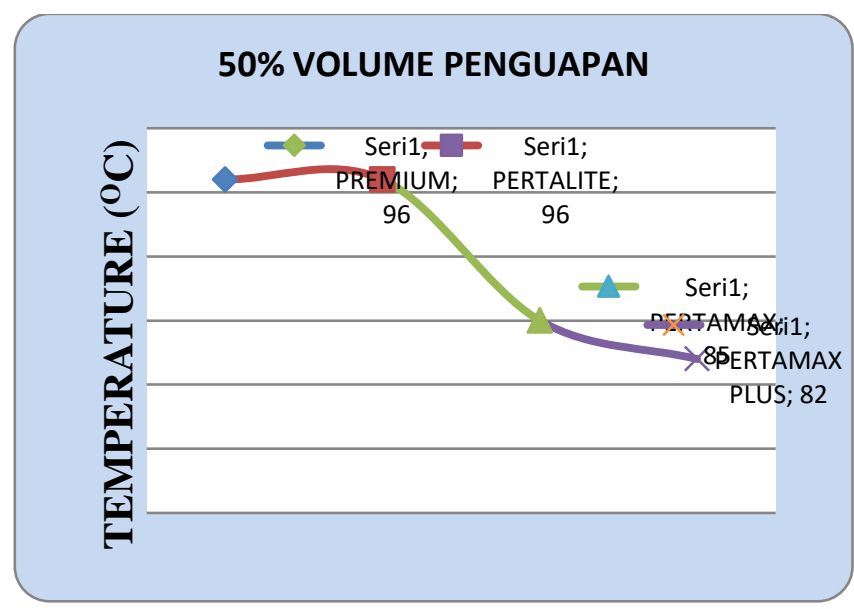

\section{Grafik 3 Distilasi 50\% Volume Penguapan}

Pengujian distilasi pada 50\% volume penguapan memegang peranan mulainya pembakaran didalam ruang bahan bakar atau mesin dan memegang peranan pada pembakaran gas yang ada disekitar ruang bahan bakar dan menentukan keselamatan saat berkendara di kondisi dingin, pada saat motor berjalan ditanjakkan mencegah terjadinya mesin berhenti tiba-tiba. 
Semakin rendah temperature yang didapat dari pengujian $50 \%$ volume penguapan maka akan semakin mudah mesin mengubah kecepatan, maka makin cepat waktu yang dibutuhkan untuk pemanasan. Spesifikasi temperature untuk pertalite dan premium adalah temperature minimum sebesar $88^{\circ} \mathrm{C}$ dan temperature maksimum sebesar $125^{\circ} \mathrm{C}$.

Sedangkan untuk spesifikasi pertamax maksimum 180 dan premium temperature minimum sebesar $75^{\circ} \mathrm{C}$ dan maksimum sebesar $125^{\circ} \mathrm{C}$. Pada sampel pengujian ini semua sampel telah memenuhi standar spesifikasi bensin yang ditentukan dari drijen migas 2006 dan 2013 untuk jenis gasoline premium, pertalite, pertamax dan pertamax plus.

Pada sampel gasoline premium,pertalite, pertamax dan pertamax plus yang di pilih, hasil pengujian yang didapat jauh lebih kecil dari batas maksimum spesifikasi yang dikeluarkan dirjen migas. Dapat di artikan bahwa sampel premium, pertalite, pertamax dan pertamax plus yang di ambil cukup aman dalam segi keamanan (safety) pada kondisi lingkungan dingin. Dari hasil pengujian sampel yang dilakukan pada distilasi50\% volume penguapan dapat diambil kesimpulan bahwa semakin tinggi angka oktan dari gasoline maka akan semakin rendah temperature yang didapat pada pengujian distilasi $50 \%$ volume penguapan.

Dalam sistem bahan bakar vapour lock dapat terjadi dimana saja. Apabila saluran bahan bakar atau karburator menjadi sangat panas, bensin akan mulai menguap, menimbulkan gelembung dalam sistim yang akhirnya dapat menghambat aliran bahan bakar dari pompa bahan bakar. Selanjutnya dapat menyebabkan mesin mati. Peranan ini dipegang pada pengujian distilasi $50 \%$ vol penguapan.

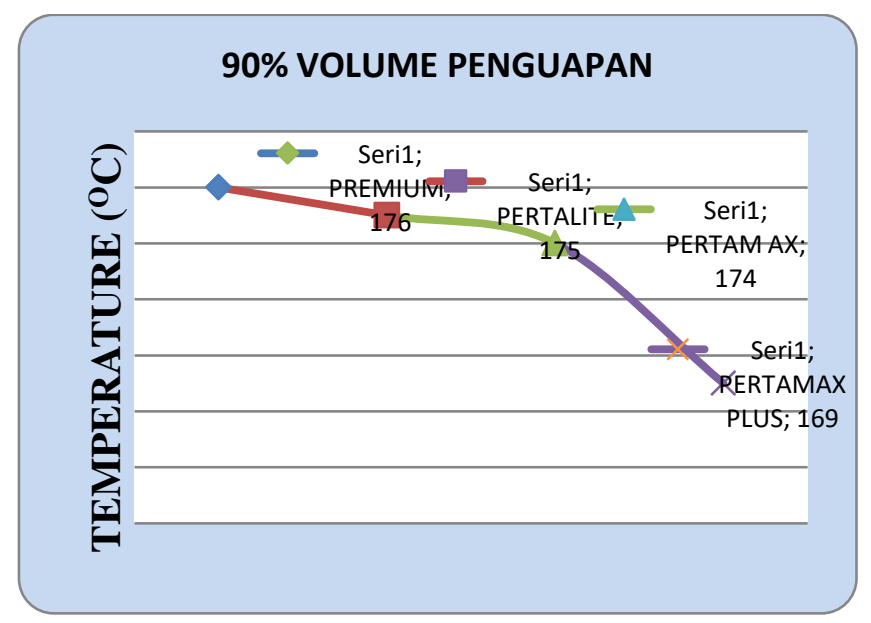

Grafik 4 Distilasi 90\% Volume Penguapan

Pada hasil pengujian dapat dilihat dari hasil garis grafik diatas sampel gasoline, makin tinggi angka oktan atau makin tinggi nilai RVP dari sampel makin rendah temperature nya pada pengujian distilasi $90 \%$ penguapan. Dapat diambil kesimpulan pada pengujian distilasi $90 \%$ volume penguapan urutan sampel yang paling bagus pada pendistribusian bahan bakar di setiap silinder mesin kendaraan adalah pertamax plus, pertamax, pertalite dan premium dilihat dari besar RVP dan temperature yang didapat saat pengujian distilasi. Semakin tinggi temperature $90 \%$ penguapan maka akan semakin tidak merata distribusi bahan bakar di setiap silinder motor, sehingga mesin akan lebih cepat panas dan rusak.

Terdapat dua macam emisi yang berkaitan dengan pemakaian bahan bakar pada kendaraan, yaitu emisi evaporatif yang berkaitan dengan penguapan bahan bakar pada saat pengisian (refueling), dan emisi pembakaran yang merupakan produk langsung pembakaran diruang bakar. Untuk emisi buangan dapat dilihat dari tabel 5.1 sampai 5.4 bahwa semakin tinggi angka oktan dari gasoline maka akan semakin rendah emisi buangan atau emisi pembakaran, dapat diartikan juga semakin besar nilai RVP dari gasoline maka akan semakin rendah emisi buangan atau emisi pembakaran. Hal ini berarti baik untuk peningkatan kualitas udara bagi manusia.

\section{KESIMPULAN}

Setelah melakukan Penelitian maka dapat disimpulkan beberapa hal sebagai berikut:

1. Dalam pengujian yang dilakukan menggunakan metode ASTM D 86 untuk mencari distilasi sedangkan untuk mencari RVP menggunakan metode ASTM D 323.

2. Berdasarkan keputusan dirjen migas spesifikasi bensin jenis premium dan pertalite memiliki spesifikasi tekanan uap reid minimum sebesar $45 \mathrm{kPa}$ dan maksimum sebesar $69 \mathrm{kPa}$. Sedangkan bensin jenis pertamax dan pertamax plus memiliki standar tekanan uap reid minimum sebesar $45 \mathrm{kPa}$ dan maksimum sebesar $60 \mathrm{kPa}$.

3. Semakin tinggi RVP dan angka oktan dari gasoline akan semakin rendah temperature yang didapat pada pengujian distilasi, di buktikan pada RVP yang tinggi dapat mengakibatkan pencapaian IBP (Initial Boiling Point) yang cepat yang dapat di artikan bahwa bahan bakar mudah menguap yang dapat memudahkan penyalaan mesin pada kondisi dingin. Semakin besar nilai RVP pada gasoline makin rendah juga temperature yang didapat dari pengujian distilasi $10 \%$ volume penguapan dan distilasi $90 \%$ volume penguapan dan semakin tinggi angka oktan dari gasoline akan semakin rendah temperature distilasi saat pengujian.

4. Semakin tinggi angka oktan dari gasoline maka akan semakin rendah emisi buangan atau emisi pembakaran, dapat diartikan juga semakin rendah nilai RVP dari gasoline maka akan semakin rendah emisi buangan atau emisi pembakaran dan semakin bagus kualitas dari gasoline itu sendiri. 


\section{DAFTAR PUSTAKA}

[1] A. Riesta, Studi Pengaruh Volatilitas Bensin Terhadap Karakteristik Lainnya Dan Kinerja Mesin. Jakarta: PPPTMGB LEMIGAS, 2009.

[2] Y. Emi, Meramu Bahan Bakar Jenis Bensin RON 91 yang Ramah Lingkungan dengan Membatasi Kandungan Senyawa Aromatik, Benzene, dan Olefin. Jakarta: PPPTMGB LEMIGAS, 2010.

[3] H. Abdullah, Pengujian Pengaruh Mutu Bahan bakar Bensin Terhadap Kemampuan Kerja Motor Bensin. Bandung: LIPI, 2009.

[4] Y. Emi, Pengaruh Kenaikan Tekanan Uap Reid Bensin (RVP) Terhadap Gejala Vapour Lock dan Konsumsi Bahan Bakar Pada Kendaraan Di Jalan Raya. Jakarta: PPPTMGB LEMIGAS, 2015. 